Journal of Learning and Development Studies (JLDS)

ISSN: 2752-9541

DOI: $10.32996 /$ jlds

Journal Homepage: www.al-kindipublisher.com/index.php/jlds

\title{
Science Learning Model in the Bilingual Class System (BCS) in Tahfidz Science Program of Man 2 Kudus
}

\author{
Choeroni $^{1} \square$ Fattah Syukur $^{2}$ and Hamdan Hadi Kusuma ${ }^{3}$ \\ ${ }^{1}$ Universitas Islam Sultan Agung, Semarang, Indonesia \\ ${ }^{12}$ Universitas Islam Negeri Walisongo, Semarang, Indonesia
}

$\square$ Corresponding Author: Choeroni, E-mail: choeroni@unissula.ac.id

\begin{tabular}{|c|c|}
\hline ARTICLE INFO & ABSTRACT \\
\hline Received: 25 Octover 2021 & \multirow{8}{*}{$\begin{array}{l}\text { This study aimed to analyze science learning in the Bilingual Class System (BCS) in the } \\
\text { Tahfidz Science Program of MAN } 2 \text { Kudus. The methodology in this study uses } \\
\text { qualitative methods. Observation, interviews, and documentation collected data. The } \\
\text { results showed that the science learning process was carried out in accordance with } \\
\text { the learning steps, namely planning, carrying out learning activities, and evaluating. } \\
\text { The BCS Program uses the Islamization model of science, scientific science, and integral } \\
\text { Islamic Science in integrating learning between religion and science. The science } \\
\text { learning model at BCS Science Tahfidz of MAN } 2 \text { Kudus is based on integrated science } \\
\text { learning in Madrasah Education units and Tahfidz al-Qur'an Islamic boarding schools } \\
\text { with the vision of creating students whose Islamic character, excel in achievement and } \\
\text { are skilled in technology by using the Guidance, Research, Intensive, Science, } \\
\text { Integration, Religion, Islamization, Scientification, Laboratory, Acculturation, } \\
\text { Mentoring, Excellence, Intellectual, Complete and Evaluative model which is } \\
\text { abbreviated as BRISIA ISLAM KITE. }\end{array}$} \\
\hline ccepted: 22 November 2021 & \\
\hline ublished: 11 December 2021 & \\
\hline DOI: 10.32996/jlds.2021.1.1.11 & \\
\hline KEYWORDS & \\
\hline Madrasah Aliyah, Pesantren & \\
\hline Tahfidz, al-Qur'an, dan Science & \\
\hline & \\
\hline
\end{tabular}

\section{Introduction}

The dichotomy in Islamic education occurs because of the rejection of Islamic scientific validity. Religious groups consider that the general knowledge studied is heretical or invalid because it comes from unbelievers, while general science activists argue that theology is false science, or in other words, as the mythology that will not reach a scientific level. This causes the distance between religious knowledge and general science to be even further ". Therefore, the integration of the two is a solution that can be offered to answer the Problem of Islamic education in this dichotomy. The integration of science clearly opens up opportunities to improve the quality of Islamic education so that it continues to develop with human progress. (Kurniawan, 2015)

Islam does not recognize a dichotomy in science; this is evidenced by the many verses of the Qur'an that command humans to seek knowledge and become scientists, such as the verse that invites humans to see, pay attention and understand events (Fathir: 27, al-Hajj: 5, Luqman: 20, al-Ghasyiyah: 17-20, Yunus:101, al-Anbiya: 30), became Ulu al-Albab (Ali Imran: 7; 190-191, al-Zumar: 18 ), and to know an event (al-An'am: 97, Yunus:5). The Qur'an also equates science at a level that is almost the same as faith, as stated in Surah Al-Mujadilah verse 11 (Fakhri, 2010).

Even the first verse that came down, namely Surah al-Alaq verses 1-5, is the foundation of the integration of science, where the word iqra' when taken from the root word, which means gathering will originate into various meanings such as conveying, studying, exploring, researching, knowing the characteristics of something and read both written and unwritten. In terms of the object, the word iqra ' command includes everything that can be reached by humans. The reviews above reinforce that there is no dichotomy between religious and non-religious knowledge in Islam (Fakhri, 2010).

From the description explained previously, in the development of Islamic educational institutions, especially in education based on tahfidz al-Qur'an boarding schools, it is necessary to have tahfidz pesantren which have the initiative to make new

Copyright: (C) 2021 the Author(s). This article is an open access article distributed under the terms and conditions of the Creative Commons Attribution (CC-BY) 4.0 license (https://creativecommons.org/licenses/by/4.0/). Published by Al-Kindi Centre for Research and Development, London, United Kingdom. 
breakthroughs, namely in addition to conducting tahfidz al-Qur'an education to students, it also combines the abilities of two languages between Arabic and English and the development of learning in the natural sciences through formal education. With this model, students are expected to be able to become intellectuals whose comprehensiveness (kaffah), where the basis of intelligence is strong and supported by qualified abilities in the field of science so that later they can become strong Muslim scientists and memorize the Qur'an .

Such a model was applied by the Billingual Class System (BCS) Program of MAN 2 Kudus in partnership with the Tahfidz al-Qur'an Islamic Boarding School Darul Barakah. In addition to teaching Tahfidz al-Qur'an education to the students, this Islamic boarding school provides foreign language skills (Arabic and English) and formal schools that focus on the Department of Science (Biology, Physics, and Chemistry). From the learning model applied, it can deliver students to the understanding and practice of learning science, even being able to deliver some of their students to several achievements in the field of science.

Seeing the development of education and achievements in al-Qur'an Islamic boarding schools that apply the strengthening of two languages and abilities in the field of science, the authors researched the model of science education in Islamic Educational Institutions based on the tahfidz al-Qur'an, so that it could finally serve as such a science learning model in Islamic educational institutions based on tahfidz al-Qur'an as an alternative in Indonesia.

\section{Research Methods}

This research is qualitative research that is intended to describe in detail the objective conditions of science learning in the Billingual Class System (BCS) Program of MAN 2 Kudus. Researchers also use a descriptive approach to try to provide an overview of the object under study through data or samples that have been collected. The research results are processed, analyzed and constructed to obtain a hypothesis or theory (Maolani, 2015).

Some data sources used to research information in the Billingual Class System (BCS) Program of MAN 2 Kudus are documents, informants, activities, locations, objects, pictures, and recordings (Nugrahani, 2014). Data collection techniques are carried out through observation; this method is carried out to obtain visual data by looking at the object of research directly. Second, interviews with key informants, namely pesantren caregivers, school principals, science teachers, students, and alumni. Third, all existing documents are selected so that the documents taken are valid data that can support the research process (Arikunto, 2010).

\section{Discussion and Findings}

\subsection{Method dan Models in Science Learning}

Learning methods are learning steps or procedures, including lesson plans and assessments to achieve learning objectives (Suyono, 2015) such as Lesson study methods, Problem-based learning, and Inquiry.

1. Lesson study is one of the efforts to improve learning processes and outcomes carried out collaboratively and sustainably by groups of teachers. Three stages must be done by the teacher, namely planning (plan), implementation (do) and reflection (see).

2. Problem-based learning (PBL) is a problem-based learning method, learning is carried out by presenting a problem to students, and students are asked to solve the problem. (Rahayu et al., 2012)

3. Inquiry is a multifaceted activity that involves various activities in the form of observing activities, asking questions, preparing books and other learning resources (Sujana, 2020)

The model is the procedure chosen in the lesson plan to achieve the goals set with systematic and sequential steps (Suheri, 2017) a science learning model that can be used as a guide in student learning, including:

1. Student Teams Achievement Division (STAD) is cooperative learning that can encourage students to cooperate actively, motivate students to support each other and help each other in mastering the abilities taught by educators; this model helps activate students in the learning process.

2. Team Assisted Individualization (TAI) is a model by forming small heterogeneous groups to help other students who need help (Kusuma, 2017). The science learning model can also use e-learning, namely any use or use of internet and web technology to create learning experiences.

3. Spiritual teaching

Spiritual attitude is very important in all aspects of life because religion will lead the direction of good human life and has character. The following is the implementation of science learning with spiritual teaching in madrasah.

a. Reflective learning is character education that is integrated or attached to all types of subjects, including Mathematics, Science, Social Sciences, Indonesian, and other subjects at all levels of education; for example, after students elaborate 
on the material about blood then the teacher asks who regulates the blood flow in humans, then the teacher pays attention to those who answer correctly and incorrectly, then the teacher sorts the students who answer wrongly to be given character strengthening about Islam, that is about surrendering to Allah the Almighty.

b. Contextual learning $(C T L)$ is learning by linking learning materials with the real world; for example, in the material for separating mixtures by practising salt bleaching $(\mathrm{NaCl})$, this material is chosen because salt is a compound that is often used in everyday life. Spiritual values can be instilled in the salt purification practicum by being grateful for the gift given by Allah SWT in the form of the ocean as a source of making salt. Students must also be able to protect the environment, especially the ocean, as a creation of Allah SWT as a form of practising Islam. (Mahmudah, 2016)

\subsection{The existence of the Tahfidz al-Qur'an Islamic Boarding School as an Islamic Education Institution.}

Pesantren is a cadre of scholars and a place where students learn knowledge from their kyai (Islamic teacher). Santri learns to understand, appreciate and practice the teachings of Islam by emphasizing the importance of morals in amaliyah in everyday life (Ahmad Shidiq, 2015). In the division of pesantren, there is a tahfidz al-Qur'an pesantren model, namely boarding schools where the main purpose of learning in pesantren is being able to memorize 30 juz of the Qur'an (Romdhoni, 2015). The Tahfidz Al-Qur'an Islamic Boarding School is currently being loved by the Muslim community, especially the boarding school model. This indicates that the Muslim community has a strong desire for their children to memorize the Qur'an. This phenomenon is an indication of the awareness of the Muslim community about the virtue of memorizing the Qur'an (Hidayah, 2016).

Tahfidz al-Qur'an Islamic boarding schools, as well as Islamic boarding schools with other models, are part of Indonesian education that carries the jargon of al-muhafazhah `ala al-qadim as Shalih wa al-akhdzu bi al-jadid al-ashlal, which means maintaining good old traditions, and take something new that is in accordance with Islam. (Pendidikan et al., 2013). After the enactment of Law Number 20 of 2003 concerning the National Education System, which eliminates discrimination against religious education, it provides opportunities to advance Islamic boarding school education (Arif, 2013).

Pesantren is the most suitable place for implementing Islamic science learning, where learning is carried out for 24 hours with a guided model. To achieve this, pesantren through their formal educational institutions such as MTs/SMP, MA/SMA/SMK must make various efforts and innovations to realize maximum science learning. Innovations that must be made include management, human resources, curriculum, as well as the fulfilment of educational facilities and infrastructure, learning processes, evaluation systems, and other matters related to education. (Damanhuri et al., 2013)

To realize this big idea in educational institutions under the auspices of Islamic boarding schools, it is necessary to change the pesantren management system to professional management where Islamic boarding schools carry out reforms in several fields, in addition to the curriculum as previously discussed, including in the field of management, building governance, and several areas of expertise such as language and skills or skills. Changes in Islamic boarding schools are necessary where pesantren are government partners in improving the quality of national education, namely increasing qualified and noble human resources. When pesantren do not open themselves from the old conventional system, certainly, the resulting outcomes will not be able to face the challenges of the global world. (Kesuma, 2017).

\subsection{The process of integrating knowledge}

Integrating knowledge has actually been going on since the emergence of Islam, started at the time of the Prophet Muhammad until now. Different methods, forms, ways and scopes (Amin, 2017). This can be seen from the process of Islamization carried out by the Prophet to the Arabs through the teachings of the Qur'an. As the main source of knowledge, Al-Quran has succeeded in releasing the Arabs from ignorance at that time. With the Qur'an, the Prophet SAW can change their perspectives of life-related humans, the universe and the life of the world.

The process was then continued by the companions, tabi'in and scholars, at which time science had brought Muslims to a very glorious period. Until the middle age, Muslim theologians and thinkers became known in the outside world, such as Al-Ghazali, AlRazi, Sayfuddin al-Amidi and others. They have succeeded in refining Ancient Greek philosophy to suit Islamic teachings, which their writings are still the main reference these days.

After the Renaissance, the glow of Islamic knowledge began to fade and was replaced by sources of knowledge from the West. Western scientists began to study Islamic scholars until Western science dominated world education. Therefore, in 1972 the issue began to be discussed among Muslim scientists in America. So that the first world conference on Islamic education was held in Mecca in 1977 with the aim that science still relies on Allah's revelation. This conference was then operationally the beginning of integrating knowledge that many people have known.

The first conference had a great influence on Muslim scientists in the world. Muslim scientists began to develop the idea of a sequential and systematic integration of knowledge that enabled it to be realized so that the problems faced by Muslims could 
immediately find a solution. As a follow-up to the first conference, which received many positive responses, then in January 1982/ Rabi'ul Awwal 1402, the second world conference was held again in Islamabad, Pakistan. In the conference, the participants agreed to review the problems faced by Muslims, both in terms of intellectual, political and economic conditions (Othman, 2009). This conference aims to inspire Muslims to conduct research and study ways out of how the idea of integrating this knowledge can be realized in literature and science.

Then the third world conference was held in Kuala Lumpur, Malaysia, in 1984. This conference aimed to develop plans for forming the foundation of Muslim thinking by focusing more on methodologies and future priorities and developing integration schemes in each discipline (Amin, 2017).

Three years later, in 1987, the fourth world conference was held in Khartoum, Sudan. The theme of this conference is "Methodology of Islamic thought in the Islamization of ethical and educational sciences". Discusses the methodological issues that are the main obstacles or challenges in implementing the Science integration program (Shole, 2004).

In Indonesia, the idea of integrating knowledge has received a positive response. This can be seen in 1978 the Islamic religious curriculum was included in compulsory subjects or subjects in every madrasah and university. This is the result of the implementation of the Makkah Conference, which was successfully formulated by the Indonesian Minister of Religion (Mas'ud, 2001).

The integration of knowledge is not enough to provide Islamic Religion material in accordance with the decision of the Ministry of Religion, but it must be more than that. As Muslims, we already know that the Qur'an is the source of knowledge. In terms of science, the Qur'an has given a signal about the development of science which is carried out to study and research scientific mysteries for the benefit of human life. (Muslih, 2017) .

\subsection{Thoughts on the Integration of Knowledge}

In this discussion, researchers only present thinkers about the Islamization of Science who are Indonesian nationals, including; Mahzar argues that religion and science are not contradictory; both have a strong and inseparable relationship, where according to him, science and religion have a mutually reinforcing integrality relationship between the two. Mahzar sees the relationship between the two from the point of view of the Qur'an and Hadith, which he later conceptualized with the term integral Islamic Science, namely the unification of natural and religious sciences as well as human and social sciences. According to him, the social sciences can be Islamized with the light of integral fighiyyah, the human sciences can be Islamized with the Sufiyah light, and the natural sciences can be Islamized with the light of monotheism (Mahzar, 2004).

Kuntowijoyo said that Islamization returned knowledge to its center, namely monotheism (monotheism). Kuntawijaya gave a new term with Islamic Science, the paradigm of Islam and Islam as Science. In implementing his thinking, Kuntowijoyo proposed three things; First, Islam as a text (al-Quran and as-Sunnah) to be faced with reality, both everyday reality and scientific reality. In other words, and text to context (text - context). Second, why do Muslims have to see reality through Islam? According to cultural science and the sociology of knowledge, the answer is that reality is not seen directly by people, but through veils (words, concepts, symbols, culture, community approval). Third, without recognizing the existence of human factors, the construction of human experience becomes incomplete Science (Kuntowijoyo, 2006).

From there, Islamic epistemology needs to be studied in depth as a new alternative to all the ironies posed by the Western epistemological system and an answer to the needs of Muslims (Mulyadi, 2003). Mulyadisaid that Western epistemology has failed to bring people to true happiness, so their lives are empty, devoid of meaning. In Western epistemology, God should not be involved in scientific explanations. It is not God who is responsible for the order of nature but nature itself. So God has been dismissed as the preserver and ruler of nature. While the main principle of scientific integration in Islam is monotheism (taulî́d), the formula: La ilaha illa Allah (There is no god but Allah). This formula is the main Islamic epistemology and becomes the basis for unity, and even the basis for the integration of human knowledge; according to him, the integration of knowledge is impossible to separate from the Islamization of Science. (Naim, 2018).

Purwanto argues that Islam and Science can be categorized into three forms, namely the Islamization of Science, which is trying to make the great scientific discoveries of the 20th century, the majority of which occurred in the West, in accordance with Islamic teachings, and Islamic scientification, which means an effort to find the basis of science in a statement that considered true in Islam. Islamic Science is an effort to make the Qur'an and as-Sunnah the basis for the construction of science, as well as an effort to make it capable of good integration with modern science that has developed previously (Yusuf, 2017).

\subsection{Implementation of Science learning in the BCS Science Tahfidz Program of MAN 2 Kudus}

1. Lesson planning 
As explained previously, planning in learning is very important for the smooth learning process and minimizing the problems that arise in it. One of the learning plans in the BCS Science Tahfidz MAN 2 Kudus Program is the division of tasks or learning schedules given at the beginning of each semester.

After the teacher receives the division of teaching tasks, what is done by the teacher is to prepare a learning syllabus and a lesson plan program according to the assigned subjects. For 2020/2021 learning RPP, 1 sheet of RPP has been used. As for the COVID19 pandemic, there is a simplification of materials with an emergency curriculum (Interview, Azhar, 2021).

\section{Learning activities}

After the lesson plan is prepared, the next stage is the teacher carrying out learning in accordance with the steps in the lesson plan. In the BCS Science Tahfidz Program MAN 2 Kudus, learning about theory is carried out in the classroom, while practical material is carried out in the school environment or in the laboratory. According to Mr Awal, for practical material in the laboratory, children are very comfortable, and they even enjoy learning in the laboratory more than in class (Interview, Awaluddin, 2021).

The delivery of teacher material in class uses several variations, including lecture and discussion materials. In addition, as demanded by the 2013 curriculum, the delivery of material must use a scientific approach, namely through the stages of observing, formulating problems, proposing or formulating hypotheses, collecting data with various techniques, analyzing data, drawing conclusions and communicating concepts, laws or principles found. (Diani, 2016)

During the learning process, the BCS Science Program teacher Tahfidz MAN 2 Kudus always associates science learning with verses of the Qur'an as when explaining the process of human creation; he associates it with several verses of the Qur'an such as the letter al-Mu'minun verse 12-14, surah al-Qiyamah verses 37-39, also in managing the environment that is associated with human duties as caliphs on earth as described in letter al-Baqarah verse 30 (Wawancara, Karsidi, 2021).

The teacher's effort in integrating religion and science apart from linking the material presented with the verses of the Qur'an is to invite students to always obey Allah SWT for His creation, such as when explaining the occurrence of photosynthesis in plants, the teacher invites students to be grateful for the blessings that have been given. Given to humans, one of which is the existence of plants whose benefits are intended for humans. In addition, there is student research conducted with teacher guidance on how the influence of the sound of reading the Koran can increase the growth of broccoli plants in the smart broccoli incubator research (Interview, Faqihuddin, 2021). From the practice of integrating religion and science according to researchers who approach the suitability of practice in the BCS Science Tahfidz MAN 2 Kudus Program is the Islamization of Science Agus Purwanto, namely aligning the findings of Western scientists with the verses of the Qur'an and scientific science, namely by trying to find the basis of science in an area. Statements that are considered true in Islam.

In addition, using Kuntowijoyo's theory, Islamic knowledge is an intellectual movement that reconnects text with context (or from text to context). Between text and context, there is a correspondence and theory put forward by Mahzar, who gives his argument when explaining the QS. al'Alaq verses 1-5 that knowledge cannot be separated from Allah. According to him, the social sciences can be Islamized with the light of integral fiqhiyyah, the human sciences can be Islamized with the Sufiyah light, and the natural sciences can be Islamized with the light of monotheism.

In classroom learning, teachers at the BCS Science Tahfidz MAN 2 Kudus Program teachers use the inquiry method in learning, which involves various activities in the form of observing activities, asking questions, preparing books and other learning resources. (Rahayu et al., 2012)

Learning in the MAN 2 Kudus laboratory is very popular with students, this is because the facilities are complete. With international standards, so they are very comfortable practising in the lab. One of the things that trigger their preference for studying in the lab is because they are motivated by the achievements that seniors have achieved in the field of research, which is carried out in the laboratory (Interview, Muspohaji, 2021).

Research learning at the BCS Science Tahfidz MAN 2 Kudus Program as carried out at MAS Tahfidz Yanbu'ul Qur'an Menawan Kudus uses a Constructivism Approach, which is a student-centred approach. There are several steps taken in developing research at MAN 2 Kudus, including through the practice of science in the laboratory, through clinical achievement or mentoring, which is carried out after 14.00 to 16.30 . In contrast, in the BCS Science Tahfidz class, it is carried out from 20.00 to 22.00 , and through mentoring. Structured research (Wawancara, Shofi, 2021).

In the first stage of research, students look for ideas related to the material. Second, after getting an idea that is thought to be good, then consult the idea to the research supervisor by presenting the student's ideas through sharpening ideas by presenting the background of the problem and the formulation of the problem. Third, after the students' ideas have been presented and have 
received input from the research teacher, they are then taken to the research coordinator to review the student's ideas at the research teacher teaching team meeting.

Fourth, after the team has approved the students' ideas, the next step is to determine the research supervisor. In one study, you can use 2 to 5 supervisors depending on the complexity of the research idea. The task of the research supervisor is to lead students or groups of students to complete the research carried out (Interview, Ulya, 2021). In applying religion-based research, MAN 2 students have also carried out, one of which is research on how the effect of reading the verses of the Qur'an on the development of plant growth. For research learning, the BCS Science Tahfidz MAN 2 Kudus Program in classroom learning uses Lesson study, Problem based learning and Inquiry methods, while for practical learning and research it uses the Student Teams Achievement Division (STAD) model, Team Assisted Individualization (TAI), and Spiritual teaching.

As the profile of Madrasah Aliyah graduates by the Ministry of Religion of the Republic of Indonesia, the expected advantage is that students can master research, Science and technology, and research learning in the BCS Science Tahfidz MAN 2 Kudus Program is carried out intensively. Intensive guidance is carried out during clinical performance hours from 20.00 until 22.00 at the Darul Barokah Islamic boarding school (Interview, Awaluddin, 2021).

3. Learning evaluation

Evaluation is one of the important things in learning, including science learning in madrasas based on the Tahfidz al-Qur'an Islamic Boarding School. Every learning activity carried out requires an evaluation or assessment to determine the level of achievement of the education program's implementation. In science learning, as an indicator of the results of science learning at MAN 2 Kudus is to get good grades in each subject with the COMPLETE CRITERIA with the Minimum Completeness Criteria (KKM) is 70 with the predicate.

Science learning indicators at MAN 2 Kudus are determined by the predetermined KKM values, such as the KKM value for class $X$ is 70, class XI is 71 , and class XII is 72. In addition, another indicator is the achievement of student science research with guidance to conduct research reports (Interview, Awaluddin, 2021). Evaluation and assessment are carried out gradually, including Class Assessments conducted by teachers in the form of Daily Assessments, Mid-Semester Assessments and Final Semester Assessments in terms of attitudes, knowledge and skills. Final Assessment of the Study Period conducted by Madrasahs in the form of Madrasah Final ExaminationsScience learning indicators at MAN 2 Kudus are determined by the predetermined KKM values such as the KKM value for class X is 70, class XI is 71, and class XII is 72. In addition, another indicator is the achievement of student science research with guidance to conduct research reports (Interview, Awaluddin, 2021). Evaluation and assessment are carried out gradually, including Class Assessments undertaken by teachers in the form of Daily Assessments, Mid-Semester Assessments and Final Semester Assessments in terms of attitudes, knowledge and skills, and Final Assessment of the Study Period conducted by Madrasahs in the form of Madrasah Final Examinations (Documentation, 2021).

According to researchers, the assessment carried out at the BCS Science Tahfidz MAN 2 Kudus Program using authentic assessment is a task requiring students to fulfil predetermined performance by applying their knowledge and skills. This assessment provides more direct experience, namely by learning by hand on activity (Supra, R Dadan, 2017)

4. Science Learning Model in the BCS Science Tahfidz Program of MAN 2 Kudus From the explanation above, it can be seen that the science learning model at BCS Science Tahfidz MAN 2 Kudus is based on integrated science learning in Madrasah Education units and Tahfidz al-Qur'an Islamic boarding schools with the vision of realizing students who have an Islamic character, excel in achievement and are skilled. In technology, using the model of guidance, research, intensive, Science, integration, religion, Islamization, scientification, laboratory, acculturation, mentoring, excellence, intellectual, Complete, and evaluative, abbreviated as BRISIA ISLAM KITE.

First, guidance. Science learning at BCS Science Tahfidz MAN 2 Kudus is guided and guided directly by competent teachers in their fields.

Second, research. BCS Science Tahfidz MAN 2 Kudus conducts research in science learning methods as a research-based school implementation.

Third, intensive. This means that the learning guidance is carried out seriously and continues to obtain maximum results.

Fourth, Science. Science in research at BCS Science Tahfidz MAN 2 Kudus is a natural science that includes Physics, Chemistry and Biology. 
Fifth, integration. In carrying out science learning, BCS Science Tahfidz MAN 2 Kudus carries out an integration process, namely the assimilation method.

Sixth, religion. What is meant by religion here is Islam, namely by assimilation between scientific material and the Qur'an (as a source of Islamic law).

Seventh, in teacher learning at BCS Science Tahfidz MAN 2 Kudus, Islamization tries to make the great scientific discoveries of the 20th century, which mostly occur in the West, according to Islamic teaching.

Eighth, scientification, a teacher at BCS Science Tahfidz MAN 2 Kudus seeks to find a scientific basis for a statement that is considered true in Islam.

Eighth, laboratory. In practising science learning, students are invited to the laboratory to carry out learning in the form of practice.

Ninth, acculturation. The process of habituation of students in foreign languages in everyday life.

Ninth, mentoring, the learning model is carried out in class and intensive mentoring by mentor teachers who accompany the research.

Tenth, excellence. The excellence of MIPA at BCS Science Tahfidz MAN 2 Kudus in the field of Science Research and Innovative Products aims to develop students' abilities in conducting basic research and creating innovative products that are beneficial to the surrounding environment.

Eleventh, intellectual. Science learning brings students to be smart students and have knowledge in accordance with current development.

Twelfth, comprehensive. Science learning that is applied at BCS Science Tahfidz MAN 2 Kudus is to use a complete model. In learning, all students are required to have the AKM threshold value.

Thirteenth, evaluative. After carrying out the learning process, one of the benchmarks for learning success is to use evaluation. Evaluation is carried out in the assessment of PAT, PAS and research results.

Figure 1:The Proposition of the Science Learning Model at the BCS Science Tahfidz Program of MAN 2 Kudus 
Science Learning Model in

Al-Qur'an Islamic Boarding

School-Based Educational

Institutions

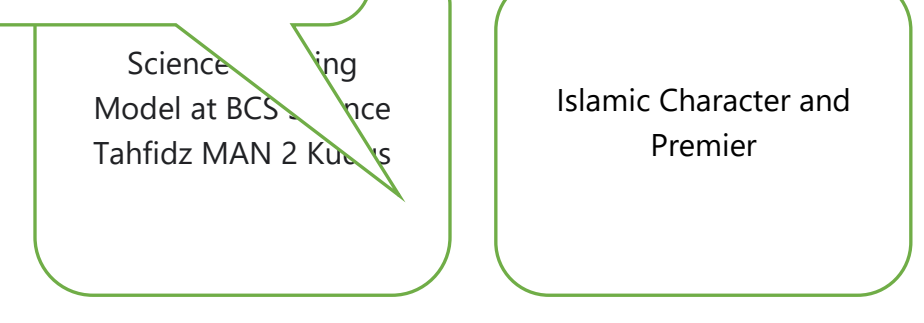

\section{Conclusion}

The BCS Science Tahfidz program of MAN 2 Kudus collaborates with partner pesantren of Darul Barokah as a role model in science learning at madrasas based on Tahfidz pesantren. The science learning process is carried out in accordance with the learning steps, namely, planning, learning activities, evaluation. In integrating religion and science, using some of the thoughts of experts on the integration of science and religion in Indonesia, such as the Islamization of Science, Agus Purwanto, who harmonizes the findings of Western scientists with the verses of the Qur'an and scientific science, that is by trying to find the basis of science on a statement that is considered true. In Islam. Kuntowijoyo said that Islamic knowledge is an intellectual movement that reconnects text with context (or from text to context), and Mahzar gives his argument when explaining QS. al'Alaq verses 1-5 that knowledge cannot be separated from Allah. According to him, the social sciences can be Islamized with the light of integral fiqhiyyah, the human sciences can be Islamized with the Sufiyah light, and the natural sciences can be Islamized with the light of monotheism.

Science learning model at BCS Science Tahfidz MAN 2 Kudus is based on integrated science learning in Madrasah Education units and Tahfidz al-Qur'an Islamic boarding schools with the vision of realizing students who have an Islamic character, excel in achievement and are skilled-in technology, using the model of guidance, research, intensive, Science, integration, religion, Islamization, scientification, laboratory, acculturation, mentoring, excellence, intellectual, Complete, and evaluative, abbreviated as BRISIA ISLAM KITE.

\section{Reference}

[1] Arikunto. S. (2010), Prosedur Penelitian, Jakarta: Rineka Cipta.

[2] Amin. K, (2017), Islamisasi Ilmu Tantangan dan Masa Depan Ilmu Pengetahuan. Semarang: Unissula Press.

[3] Dhiauddin, I, (2019) Science dan Teknologi; Sebuah Konsep Integralisme Islam (Studi Kritis Pemikiran Armahedi Mahzar), Malang; CV. Literasi Nusantara Abadi. 
[4] Kuntowijoyo, (2006), Islam Sebagai Ilmu; Epistimologi, Metodologi dan Etika, Yogyakarta : Tiara Wacana.Amin. Kurdi, (2017), Islamisasi Ilmu Tantangan dan Masa Depan Ilmu Pengetahuan. Semarang: Unissula Press.

[5] Mahzar, A (2004), Merumuskan Paradigma Sain dan Teknologi Islami;Revolusi Integralisme Islam, Bandung: Mizan.

[6] Maolani, R. A. dan Cahyana. (2015). Metodologi Penelitian Pendidikan. Jakarta: PT. Rajagrafindo Persada

[7] Mas'ud, A. (2001), Paradigma Pendidikan Islam., Yogyakarta: Pustaka Pelajar.

[8] Mulyadhi K, (2003), Menyibak Tirai Kejahilan, Pengantar Epistemologi Islam, Bandung: Mizan.

[9] Nugrahani, F. (2014), Metode Penelitian Kualitatif dalam Penelitian Pendidikan Bahasa, Solo:Cakra Books.

[10] Othman, M. A. (2009), Islamization of Human Sciences: Problems and Prospects. Malaysia: IIUM Press.

[11] Sholeh. K. (2004), Wacana Baru Filsafat Islam, Yogyakarta: Pustaka Pelajar.

[12] Sujana, A. (2020), Model-model pembelajaran Inovatif Teori dan Implementasi, Depok: Raja Grafindo Persada.

[13] Suyono \& Hariyanto, (2015), Belajar dan Pembelajaran : Teori dan Konsep Dasar, Bandung : PT. Rosdakarya.

[14] Theo H. (1982), Filsafat Hukum dalam Lintasan Sejarah, Jogjakarta: Kanisius.

[15] A, S. Q., \& Hijrawan, R. (2021). Membaca Pemikiran Kuntowijoyo dalam Hubungan Ilmu dan Agama Perspektif Islam. Qalamuna- Jurnal Pendidikan, Sosial, Dan Agama, 13(1), 129-144. https://doi.org/10.37680/qalamuna.v13i1.568

[16] Ahmad S. (2015). Tradisi Akademik Pesantren. Tadris, 10(1), 218-229. https://doi.org/http://dx.doi.org/10.19105/tjpi.v10i2.826

[17] Arif, M. (2013). Perkembangan pesantren di era teknologi. Jurnal Pendidikan Islam, 28(2), 307-322. https://doi.org/https://doi.org/10.15575/jpi.v28i2.550

[18] Damanhuri, A., Mujahidin, E., \& Hafidhuddin, D. (2013). Inovasi Pengelolaan Pesantren dalam Menghadapi Persaingan di Era Globalisasi. Ta'dibuna: Jurnal Pendidikan Islam, 2(1), 17. https://doi.org/10.32832/tadibuna.v2i1.547

[19] Diani, R. (2016). Pengaruh Pendekatan Saintifik Berbantukan LKS Terhadap Hasil Belajar Fisika Peserta Didik Kelas XI MA Perintis 1 Bandar Lampung. Jurnal Ilmiah Pendidikan Fisika 'Al-BiRuNi,' 05(April), 83-93. https://doi.org/10.24042/jpifalbiruni.v5i1.108

[20] Fakhri, J. (2010). Science dan Teknologi dalam al-Qur'an dan Implikasinya dalam Pembelajaran. Ta'dib, XV(01), 121-142. https://doi.org/https://doi.org/10.19109/td.v15i01.70

[21] Hidayah, N. (2016). Strategi Pembelajaran Tahfidz Al-Qur'an di Lembaga Pendidikan. Ta'allum, 04(01), 63-81. https://doi.org/https://doi.org/10.21274/taalum.2016.4.1.63-81

[22] Kesuma, G. C. (2017). Refleksi Model Pendidikan Pesantren dan Tantangannya Masa Kini. 02(1), 67-79. https://doi.org/10.24042/tadris.v2i1.1740

[23] Kurniawan, S. (2015). Reconcile the religion and science education management in Islam. Ta'dib: Journal of Islamic Education, 20 (1), 103-129. https://doi.org/https://doi.org/10.19109/td.v20i1.221

[24] Mahmudah, L. (2016). Spiritual Teaching dalam Pembelajaran IPA di Madrasah. Educasia, 11(2), 443-464. https://doi.org/http://dx.doi.org/10.21043/edukasia.v11i2.1787

[25] Muslih. (2018). Pembelajaran Ayat-ayat Kauwniyah di SMA Trenscience 2 Pesantren Tebuireng Jombang. Islamica, 12(2), $455-480$.

[26] Muslih, M. (2017). Al-Qur' an dan Lahirnya Science Teistik. Tsaqafah, 12(November 2016), 257-280. https://doi.org/10.21111/tsaqafah.v12i2.756

[27] Naim, N. (2018). MYSTICO-PHILOSOPHY The Integration Epistemologies of Mulyadhi Kartanegara. 361-379. https://doi.org/10.21274/epis.2018.13.2.361-379

[28] Pendidikan, J., Vol, I., \& Email, S. P. (2013). Islamisasi Pengetahuan dan Model Pengembangannya pada Madrasah. Nadwa| Jurnal Pendidikan Islam, 7(2), 247-266. https://doi.org/http://dx.doi.org/10.21580/nw.2013.7.2.561

[29] Rahayu, P., Mulyani, S., \& Miswadi, S. S. (2012). Pengambangan Pembelajaran IPA Terpadu dengan Menggunakan Model Pembelajaran Problem Base Melalui Lesson Study. Jurnal Pendidikan IPA Indonesia, 1(1), 63-70.

[30] Ridwan, D. (2018). Teori Epistemologi Islam; Telaah Kritis Pemikiran Mulyadhi Kartanegara. Siasat, 2(2), 1-8. https://doi.org/10.33258/siasat.v1i2.32

[31] Romdhoni, A. (2015). Tradisi Hafalan Qur' an di Masyarakat Muslim Indonesia. Journal of Qur'an and Hadith Studies, 4(1), 1-18. https://doi.org/https://doi.org/10.15408/quhas.v4i1.2280 Abstract - 0 PDF - 0

[32] Suheri. (2017). Konstruksi Kurikulum Pesantren dalam Pendekatan, Model, Metode Pembelajaran. JALIE, 01(01), $133-145$. https://doi.org/http://dx.doi.org/10.33754/jalie.v1i1.94

[33] Supra, R Dadan, R. M. \& D. K. D. (2017). Performance Assessment Instrumen of Science Process Skills Conform The Nature Of Scince. Cakrawala Pendidikan, 36(3), 435-445. https://doi.org/https://doi.org/10.21831/cp.v36i3.14731

[34] Yusuf, M. Y. (2017). Epistimologi Science Islam Prespektif Agus Purwanto. Analisis: Jurnal Studi Keislaman, 17(1), 65. https://doi.org/10.24042/ajsk.v17i1.898

\section{Interview}

[1] Interview with Drs. H. Shofi, M. Ag (Head of MAN 2 Kudus), on April 30, 2020.

[2] Interview with Azhar Latif, ST (Waka Curriculum MAN 2 Kudus), on April 30, 2020.

[3] Interview with Ardian Awaluddin, S.Pd, M.Si (Head of Research and Technology Development of MAN 2 Kudus), on September $15,2021$.

[4] Interview with M. Muspohaji, S.Pd, M. Si (Head of IPA Lab. MAN 2 Kudus), on September 15, 2021.

[5] Interview with Drs. H. Karsidi, M. Pd (Teacher of Biology at MAN 2 Kudus), on April 30, 2020.

[6] Interview with Muhammad Mufid Faqihuddin, M. Pd (Student of class XII MAN 2 Kudus), on April 30, 2020.

\section{Observation}

[1] Direct observation to Mrs. Eka Dina Dzawil Ulya, S.Pd when guiding students to express ideas to get a research title on September 15, 2021.

[2] Direct observation to Mutiara Hapsari, S.Pd when guiding students to practice Chemistry learning on September 15, 2021.

[3] Direct observation to Mrs. Qosidah, S.Pd when delivering Physics lessons in Class on September 15, 2021. 


\section{Documentation}

[1] Documentation of BCS Science Tahfidz MAN2 Kudus Profile, taken on April 30, 2020. 